\title{
ANALYSIS OF EMPLOYEE JOB SATISFACTION IN FOOD \& BEVERAGE SERVICE AT INTERCONTINENTAL BALI RESORT
}

\author{
A.A. Ayu Oka Mirah Wahyuni, I Gusti Ngurah Agung Suprastayasa, \\ Mahendra Adi Winatha, Hilda Apriani \\ Politeknik Pariwisata Bali \\ gungmirahwahyuni@gmail.com
}

\begin{abstract}
Many studies have demonstrated a large impact on the job satisfaction and the way it influences productivity of employee or staff performance in order to increase hotel performance. This research is focused on analyzing employee job satisfaction level at InterContinental Bali Resort using Gruneberg Job Satisfaction Model as main theory. The data on this study gathered by distributing questionnaires and conducting interviews. After that, the result of it will be analyzed in quantitative and qualitative methods. The result from the research is most employees in Food \& Beverage Service at Intercontinental Bali Resort are satisfied with the indicators stated by Gruneberg theory, however some improvements was addressed and findings were discussed.
\end{abstract}

Keywords: Employee, Job Satisfaction, Gruneberg Theory of Job Satisfaction.

\begin{abstract}
Abstrak
Banyak penelitian telah menunjukkan dampak yang besar terhadap kepuasan kerja dan pengaruhnya terhadap produktivitas kinerja karyawan atau staf dalam rangka meningkatkan kinerja hotel. Penelitian ini difokuskan untuk menganalisis tingkat kepuasan kerja karyawan di InterContinental Bali Resort dengan menggunakan teori utama Gruneberg Job Satisfaction Model. Pengumpulan data dalam penelitian ini dilakukan dengan menyebarkan kuesioner dan melakukan wawancara. Setelah itu hasilnya dianalisis secara kuantitatif dan kualitatif. Hasil dari penelitian ini adalah sebagian besar karyawan Food \& Beverage Service di Intercontinental Bali Resort merasa puas dengan indikator yang dikemukakan oleh teori Gruneberg, namun beberapa perbaikan telah diatasi dan beberapa temuan didiskusikan.
\end{abstract}

\section{A. INTRODUCTION}

InterContinental Bali Resort as one of five-stars hotels Bali are also expected to be able competing with other similar hotels. Considering the competitive environment is in line with the number of accommodations that increasing, making the competition become harder. So, InterContinental Bali resort need to be careful and pay attention to the quality of its performance that affected by human resources management, such as the level of employee job satisfaction. InterContinental Bali Resort believes that the level of employee job satisfaction issues is important, because InterContinental Bali Resort concern on employee job satisfaction has successfully brought them to the point where the turnover rate is good for the past five years, especially in Food and Beverage Service department. Referring to that situation based on interview with FB manager, the Food and Beverage Service management wants to analyze more on how the company has satisfied the employees and seek for ideas how to maintain their good performance (Ariana, 2020). For InterContinental Bali Resort, a successful result in keeping the good result on employee job satisfaction would be beneficial for human resource management of the Food and Beverage Management where it can be used as a reference on establishing fundamental human resources policies in the future. Vaughn and Dunn, 1974 defined job satisfaction as "the feelings and employee has about his 
pay, work, promotion opportunities, coworkers, and supervisors". Job satisfaction also described as a pleasurable or positive emotional state resulting from the self-appraisal of one's job or job experiences (Edwin Locke, 1976).

According to (Gruneberg, 1979) there are context and content factors that affecting employee job satisfaction and it can be divided into seven-part. First part is pay to illustrate which means the company must pay the employee once-a-month with the basic salary that fulfilled the daily needs of each employee. The second part is security where an employee does not have look for the second job because she/he can count the job as a long-term income. The third part is workgroups working environment is one of the important factors of employee job satisfaction. It is because a supportive co-worker will able to support another individual mentally. The fourth part is participation which means whenever there is a condition where we have to make a decision, a leader will allow a group member to express their opinion. For the five part is role conflict where every organization has their chart to show their position and their job description must equally with their position. As for the sixth part is supervision, in the other words every individual must feel that their superior leadership style first their work pattern and be able to guide their subordinate also be able to provide positive feedback. The last part is an organizational structure, every employee must feel that their workplace is also part of their family, therefore, they will easily communicate one to another.

Gruneberg's theory also has content factors or internal factor can be divided into four-part. The first factor is recognition which means every individual, in particular, must feel that the company has a fair promotion and rewarding system. For the second part is the application of skill where the individual can have the freedom to decide how they complete their job. As for the third part is job involvement, where the employees feel that their job is a part of their identity. The last part, it is success in which every employee has to feel capable to complete their work and find that every job they do is important. The more indicator inside the employment that has equality with the individual, the higher of employee job satisfaction can be feel by the individual.

Table 1. Empirical Review of The Research

\begin{tabular}{llll}
\hline \multirow{2}{*}{ Author } & \multicolumn{3}{c}{ Job Satisfaction Theory } \\
\cline { 2 - 4 } & Gruneberg & Herzberg & Maslow \\
& (1979) & (1959) & (1954) \\
\hline Md.Anhar Sharif Mollah (2015) & $\sqrt{ }$ & $\sqrt{ }$ & $\sqrt{ }$ \\
\hline Anju K J \& Sona George (2015) & $\sqrt{ }$ & $\sqrt{ }$ & $\sqrt{ }$ \\
\hline Ahmed Azumah, Ayisha and Mohammed, & & & \\
Safura and Tetteh Rebecca (2017) & & &
\end{tabular}

By considering those previous researches, this research will use similar design to one done by Mollah (Mollah, 2015). In general, his research is about analysis on Apple UK staff job satisfaction in Apple Company. This research attempt to know whether the staff is satisfied with the elements of satisfaction identified in the survey, sufficient salary, flexible working place, flexible working hours, flexible shifts, improvement of personal requirement, balance with life and work, improve the working environments, team work, respect and good behavior get from the managements, give freedom to express the opinion. The study reviewed the literature on the concepts of job satisfaction and performance.

The study indicated that elements of job satisfaction influence overall job satisfaction. Finally, the study revealed that managements of the company should take into account the findings of the current study in knowing the things that cause employee satisfaction for enhance performance resulting from better service and quality of product. This research will also concern about employee job satisfaction in food \& beverage front service at InterContinental Bali Resort supported by Gruneberg (1979) eleven indicators of employee job satisfaction theory.

2 | Barista: Jurnal Kajian Bahasa dan Pariwisata, Volume 7 Nomor 1, 2020: 1-11 
The scope and limitation of this research is it will focus on the satisfaction level of each employee in InterContinental Bali Resort. The respondents for the research will involve food and beverage outlet staff that working in InterContinental Bali Resort. Also, the research will be based on the Gruneberg theory of job satisfaction (1979). The research aimed to analyze the job satisfaction level in Food and Beverage Department at InterContinental Bali Resort. The objective of this research is the The result of this research will be important for InterContinental Bali Resort to be used as a reference to study which factors that affecting the satisfaction level of the employee which need to be improved in InterContinental Bali Resort the most by giving suggestion to maintain the good result on employee job satisfaction at Food and Beverage Department at InterContinental Bali Resort.

\section{B. RESEARCH METHODS}

In this research, the methods that used is mix methods which involving both quantitative and qualitative data. The qualitative data in this research is obtained from interview with the hotel employee and result of observation. As for the quantitative data, it will be in form of total employee in Food \& Beverage Department and questionnaires data about employee job satisfaction in InterContinental Bali Resort.For the data collection of this study, the researcher uses both primary and secondary data. The primary data is obtained directly from questionnaire, and results from interviews with the employee regarding employee job satisfaction in InterContinental Bali Resort, while for the secondary data it gathered from articles and journal related with employee job satisfaction, and document from HR regarding hotel's information in general.

The population of this research are all employees in Food \& Beverage Service Department in InterContinental Bali Resort. Sampling method that will be used for this research is saturated sampling where all the employee population from 2 food and beverage outlet that still active due to Covid-19 situation become sample with total people is 31 persons since other outlet need to close in this pandemic situation. Moreover, to support this research the triangulation data is gathered for data validation. It consists of three different sources of the data such as; hotel's employee, hospitality senior practitioner, the general manager, and research with interest that related to hospitality studies.

\section{RESULT AND ANALYSIS}

In this research, the validity and reliability test are done by using the 31 employees from food \& beverage department in InterContinental. According to (Singarimbun \& Efendi, 1995) the minimum amount of trial of the questionnaire is 30 respondents. So within the amount of 31 peoples the distribution score will be close to the normal curve. Then, the data gained will be processed with SPSS system.

The criteria to make a decision about the validity of an instrument can be consulted with $r$ table product-moment (Sugiyono, 2010). An item can be declared as a valid indicator variable if it has the correlation coefficient score with all of the items that incorporated into the same indicator, at least 0,30 and has the same sign with the other correlation coefficient score. The result shows that the score of $r$ counted for all items is bigger than a threshold value which is 0.355 . So, all of the items can be stated as valid.

As for the decision-making in the reliability test is if the Cronbach's Alpha score is $>0,60$ then the questionnaire can be stated reliable or consistent, however, if the Cronbach's Alpha score $<0,60$ that means the questionnaire can be stated not reliable or not consistent. After the data processed, the result shows that the coefficient score of Alpha Cronbach is 0.875 which is exceeding the threshold value which is 0.60 . From that, all of the items in this research can be stated as reliable. In this research, the validity and reliability test only done once. It is because when the first validity and reliability test was done, it already fulfilled the requirement of valid and reliable. 
The list item of the questionnaire encompasses the issues that have a relation with job recognition, application of skill, job involvement, pay, security, work-groups, supervision, participation, role conflict, and organizational structure (Gruneberg, 1979). Mean score is the most common measure of central tendency and refers to the average value or score of a group of numbers (Sykes, 2016). To calculate the average score for each questionnaire item we can use mean score formula to get the total score for every research components.

Table 2. Percentage of Respondent Characteristic

\begin{tabular}{|c|c|c|c|}
\hline \multicolumn{2}{|c|}{ Age } & \multicolumn{2}{c|}{ Gender } \\
\hline $21-35$ & $36-49$ & Female & Male \\
16 & 15 & 14 people & 17 \\
people & people & & people \\
\hline $51,6 \%$ & $48.4 \%$ & $45 \%$ & $55 \%$ \\
\hline
\end{tabular}

The questionnaire has been filled by 31 respondents divide by 14 females and 17 males. Every respondent only able to choose one answer and the scoring for the answer is within the range from 1 - 5 where each score has different meaning. For score 1 means strongly disagree (STD), score 2 means disagree (DS), score means 3 neutral (N), score 4 means agree (AG), and score 5 means strongly agree (SAG). In analyzing the data, the questionnaire item is consisting of 22 items that using Likert scale which has five levels of answers where in each of level has score 1 until 5 (Sugiyono, 2010). It will be interpreted based on the attitude range.

\begin{tabular}{|c|c|c|}
\hline Group of Indicator & Mean Score & AR \\
\hline Recognition (A) & 4.8 & SA \\
\hline Application of Skill (B) & 4.9 & SA \\
\hline Job Involvement (C) & 4.9 & SA \\
\hline Success (D) & 4.9 & SA \\
\hline Pay (E) & 4.5 & SA \\
\hline Security (F) & 4.2 & AG \\
\hline Work Group (G) & 4.7 & SA \\
\hline Supervision (H) & 4.8 & SA \\
\hline Participation (I) & 4.7 & SA \\
\hline Role Conflict (J) & 4.8 & SA \\
\hline Organization Structure (K) & 4.8 & SA \\
\hline Overall & 4.7 & SA \\
\hline
\end{tabular}

All of those scores show that the respondent satisfied with their job as it stated in the questionnaire. From the results above we can see that there are two indicators with lowest score which are pay and security. Based on forum group discussion, triangulation data and hospitality senior practitioner, famous 5 star-rated hotel tend to have high score on employee job satisfaction, so if the score is 4.5 or lowest it can be categorized as low score. The results of the lowest score will be analyze in detail using cross tabulation in order to help the hotel improving their employee job satisfaction especially for those indicators.

According to (Aprameya, 2016), cross tabulation is a method to quantitatively analyze the relationship between multiple variables. Also known as contingency tables or cross tabs, cross tabulation groups variables to understand the correlation between different variables. It also shows how correlations change from one variable grouping to another. It is usually used in statistical analysis to find patterns, trends, and probabilities within raw data.

4 Barista: Jurnal Kajian Bahasa dan Pariwisata, Volume 7 Nomor 1, 2020: 1-11 
Table 5. Cross Tabulation Pay

\begin{tabular}{|c|c|c|c|c|c|c|c|c|}
\hline \multirow[b]{2}{*}{ Statements } & \multicolumn{2}{|c|}{ Characteristics } & \multicolumn{6}{|c|}{ Likert Scale } \\
\hline & Age & Gender & 1 & 2 & 3 & 4 & 5 & $\begin{array}{c}\text { Total } \\
\text { Employe } \\
\mathrm{e}\end{array}$ \\
\hline \multirow{6}{*}{$\begin{array}{l}\text { The company } \\
\text { gives me } \\
\text { wages that } \\
\text { matches my } \\
\text { performance } \\
\text { at work }\end{array}$} & \multirow{2}{*}{$\begin{array}{c}21- \\
35\end{array}$} & Male & - & - & - & 1 & 7 & 8 \\
\hline & & Female & - & - & - & 1 & 6 & 7 \\
\hline & \multicolumn{2}{|c|}{$\%$} & - & - & - & $13.3 \%$ & $86.7 \%$ & $48.4 \%$ \\
\hline & \multirow{2}{*}{$\begin{array}{c}36- \\
49\end{array}$} & Male & 2 & - & - & 1 & 6 & 9 \\
\hline & & Female & - & - & - & 1 & 6 & 7 \\
\hline & & $\%$ & $12.5 \%$ & - & - & $12.5 \%$ & $75 \%$ & $51.6 \%$ \\
\hline \multicolumn{3}{|c|}{ Total Score } & 2 & - & - & 4 & 25 & 31 \\
\hline \multicolumn{3}{|c|}{ Total \% } & $6.5 \%$ & - & - & $12.9 \%$ & $80.6 \%$ & $100 \%$ \\
\hline \multirow{6}{*}{$\begin{array}{l}\text { I'm able to pay } \\
\text { for my daily } \\
\text { needs with the } \\
\text { current wages } \\
\text { given by the } \\
\text { company }\end{array}$} & \multirow{2}{*}{$\begin{array}{c}21- \\
35\end{array}$} & Male & - & - & - & 2 & 6 & 8 \\
\hline & & Female & - & - & - & 1 & 6 & 7 \\
\hline & \multicolumn{2}{|c|}{$\%$} & - & - & - & $20 \%$ & $80 \%$ & $48.4 \%$ \\
\hline & \multirow{2}{*}{$\begin{array}{c}36- \\
49\end{array}$} & Male & - & - & 2 & 1 & 6 & 9 \\
\hline & & Female & - & - & - & 2 & 5 & 7 \\
\hline & \multicolumn{2}{|c|}{$\%$} & - & - & $\begin{array}{c}12.5 \\
\%\end{array}$ & $\begin{array}{c}18.75 \\
\%\end{array}$ & $\begin{array}{c}68.75 \\
\%\end{array}$ & $51.6 \%$ \\
\hline \multicolumn{3}{|c|}{ Total Score } & - & - & 2 & 6 & 23 & 31 \\
\hline \multicolumn{3}{|c|}{ Total \% } & - & - & $\begin{array}{c}6.45 \\
\%\end{array}$ & $\begin{array}{c}19.35 \\
\%\end{array}$ & $79.2 \%$ & $100 \%$ \\
\hline
\end{tabular}

From the Table 5, we can see the result of cross tabulation for pay indicator, especially for the first statement, it shows that there are 2 male employee from total 16 employees with range age from 36 - 49 years who are giving low score which is 1 . From the interview with the respondents, it shows that this things happened because the respondents think that the wages given by the company didn't matches their working performance. It is because the work or job description between male and female is kind of different. From the gender side, the male need to do heavier work than the woman because of the physical different also, because of the respondent is senior employee, he think that the wages given isn't quiet match his performance in his age.

On second statement, the lowest score given by the employee is 3 . There are 2 male employee people from 16 employee with range age $36-49$ years who give neutral score which is 3 . This mean that they are not sure whether their current wages can pay their daily needs. The manager also admitted that this thing affected by Covid-19 that impacting the world economy, which makes the hotel need to do reduction on employee wages to reduce the operating cost so they can keep operating. As for the 2 male employee that can be considered as (old employee due to the age) feeling unsure because as the head of the family, they need to feed their family and they also have children that still in school. The reduction of the wages might be fine for several months but they are not sure until when it will be enough because of there's no clear information about when this pandemic situation will be over.

As for the rest of employee especially for the young employee with range age 21 - 35 years, where some of them haven't married yet or just married with no children yet they tend to give score 4 or even 5 because they think they still fine and able to fulfill their daily need with their current wages. Seeing from the table above, there are also old or senior employee with age range 36- 49 years who give score 4 and 5 who feel sure that their wages can fulfill their daily needs for current situation. Thus to ensure the employee job satisfaction regarding their payment in the hotel, the management need to do improvement for pay indicator even in this COVID-19 situation. Distributing written survey related with the employee payment is recommended to know what the employee actually feel about their wages in current situation. So the management, can find a way to improve employee job satisfaction. 
Table 6. Cross Tabulation Security

\begin{tabular}{|c|c|c|c|c|c|c|c|c|}
\hline \multirow[b]{2}{*}{ Statements } & \multicolumn{2}{|c|}{ Characteristics } & \multicolumn{6}{|c|}{ Likert Scale } \\
\hline & Age & Gender & 1 & 2 & 3 & 4 & 5 & $\begin{array}{c}\text { Total } \\
\text { Employee }\end{array}$ \\
\hline \multirow{6}{*}{$\begin{array}{l}\text { I have no } \\
\text { anxiety or } \\
\text { worry } \\
\text { about } \\
\text { losing my } \\
\text { current job }\end{array}$} & \multirow{2}{*}{$\begin{array}{c}21- \\
35\end{array}$} & Male & - & - & 1 & 1 & 6 & 8 \\
\hline & & Female & - & - & 2 & 1 & 4 & 7 \\
\hline & \multicolumn{2}{|c|}{$\%$} & - & - & $20 \%$ & $13.3 \%$ & $66.7 \%$ & $48.4 \%$ \\
\hline & \multirow{2}{*}{$\begin{array}{c}36- \\
49\end{array}$} & Male & 3 & - & 2 & 1 & 3 & 9 \\
\hline & & Female & 2 & - & 1 & 1 & 3 & 7 \\
\hline & \multicolumn{2}{|c|}{$\%$} & $31.3 \%$ & - & $18.7 \%$ & $12.5 \%$ & $37.5 \%$ & $51.6 \%$ \\
\hline \multicolumn{3}{|c|}{ Total Score } & 5 & - & 6 & 4 & 16 & 31 \\
\hline \multicolumn{3}{|c|}{ Total \% } & $16.15 \%$ & - & $19.35 \%$ & $12.9 \%$ & $51.6 \%$ & $100 \%$ \\
\hline \multirow{6}{*}{$\begin{array}{l}\text { My current } \\
\text { wages can } \\
\text { be used for } \\
\text { my future } \\
\text { needs or in } \\
\text { the long } \\
\text { run }\end{array}$} & \multirow{2}{*}{$\begin{array}{c}21- \\
35\end{array}$} & Male & - & - & - & 3 & 5 & 8 \\
\hline & & Female & - & - & - & 2 & 5 & 7 \\
\hline & \multicolumn{2}{|c|}{$\%$} & - & - & - & $33.3 \%$ & $66.7 \%$ & $48.4 \%$ \\
\hline & \multirow{2}{*}{$\begin{array}{c}36- \\
49\end{array}$} & Male & - & - & 2 & 2 & 5 & 9 \\
\hline & & Female & - & - & - & 2 & 5 & 7 \\
\hline & & $\%$ & - & - & $12.5 \%$ & $25 \%$ & $62.5 \%$ & $51.6 \%$ \\
\hline \multicolumn{3}{|c|}{ Total Score } & - & - & 2 & 9 & 20 & 31 \\
\hline \multicolumn{3}{|c|}{ Total \% } & - & - & $6.5 \%$ & $29 \%$ & $64.5 \%$ & $100 \%$ \\
\hline
\end{tabular}

From the data in Table 6, we can see the result of cross tabulation for security indicator for first statement, it shows that there are 5 people which are 3 male and 2 female from 16 employees with range age from $36-49$ years who are giving low score which is 1 . From the interview with the respondents who give low score, they said in this COVID-19 situation they indeed feel afraid to lose their job especially in their age that not young anymore. It will be hard for them to look for the job in hospitality industry since the industry must be looking for fresh young people who still have lot energy and healthier than old people.

There are also 6 people from total 31 employee who give score 3. Despite of their young and old age also the gender, they feel not sure whether they should be afraid or just okay with their job security in this current situation. It's because they feel grateful that the hotel still operating and they still get their wages even there's reduction. As for the data on table it shows that the number of male employees who give score 3 is bigger than the female. It's because they are the head of family who responsible to take care of the family, so it makes them more aware about the current situation.

As for the result of second statement, we can see that the lowest score given by the employee is 3 . There are 2 male employees from 16 employees with range age 36 - 49 years who give neutral score which is 3 . From the interview, they are worry whether their current wages can be used for future needs or long run because of this current situation which is unpredictable. Since they are male and act as the head of family, they have the responsibility to provide enough resources such as; children school fee and unpredictable cost like go to hospital when they are sick.

As for the rest of employee especially for the young employee with range age $21-35$ years, where some of them haven't married yet or just married with no children yet they tend to give score 4 or even 5 because they think they still young and if something unpredictable happened to the hotel, they still able to find or do other works. Seeing from the table above, there are also old or senior employee with age range 36 - 49 years who give score 4 and 5. It's because they trust the hotel security since they have working contract with the hotel. Thus to ensure the employee job satisfaction regarding their security in the hotel, the management need to do improvement for security indicator in this COVID-19 situation. Distributing written survey related with the employee security is recommended to know what the employee actually feel about their security in current situation. So the management, can find a way to improve employee job satisfaction.

6 | Barista: Jurnal Kajian Bahasa dan Pariwisata, Volume 7 Nomor 1, 2020: 1-11 
Beside those two criteria above that have lowest score based on the questionnaire survey, other criteria also need improvements or maintenance will be shown below.

Table 7. Other Indicators that Need Improvements

\begin{tabular}{|c|c|}
\hline Indicator & Mean Score \\
\hline \multicolumn{2}{|l|}{ Recognition } \\
\hline I get an award when I'm able to complete the task well. & 4.81 \\
\hline My colleague give me a praise when I can complete the tasks given well. & 4.87 \\
\hline \multicolumn{2}{|l|}{ Application of Skills } \\
\hline $\begin{array}{l}\text { I feel I can do my job well and already in accordance with company } \\
\text { standards. }\end{array}$ & 4.93 \\
\hline $\begin{array}{l}\text { I have good skills and competencies and it's related to my current job } \\
\text { position. }\end{array}$ & 4.93 \\
\hline \multicolumn{2}{|l|}{ Job Involvement } \\
\hline $\begin{array}{l}\text { I feel happy to be able working at InterContinental Bali Resort and I feel my } \\
\text { work can reflect my identity. }\end{array}$ & 5 \\
\hline I feel proud with the work that I currently do. & 4.94 \\
\hline \multicolumn{2}{|l|}{ Success } \\
\hline $\begin{array}{l}\text { The place where I work giving a variety of jobs so that I can apply my work } \\
\text { skills. }\end{array}$ & 4.87 \\
\hline I always consider all the work that I do as important work. & 5 \\
\hline \multicolumn{2}{|l|}{ Work Group } \\
\hline $\begin{array}{l}\text { My colleague provides assistance when I am having difficulty in doing my } \\
\text { work. }\end{array}$ & 4.61 \\
\hline $\begin{array}{l}\text { My colleagues and I have a good team performance when we have to do } \\
\text { work as a team. }\end{array}$ & 4.94 \\
\hline \multicolumn{2}{|l|}{ Supervision } \\
\hline $\begin{array}{l}\text { My boss already giving clear direction regarding the division of each task } \\
\text { that should be done. }\end{array}$ & 4.87 \\
\hline I get constructive input from my supervisor regarding my performance. & 4.87 \\
\hline \multicolumn{2}{|l|}{ Participation } \\
\hline $\begin{array}{l}\text { The management give me the opportunity if I wanted to give advice for } \\
\text { management. }\end{array}$ & 4.77 \\
\hline The management considering my advice when they had to make a decision. & 4.77 \\
\hline \multicolumn{2}{|l|}{ Role Conflict } \\
\hline I can understand my job well at work. & 4.87 \\
\hline I understand the purpose of my duties in doing my work. & 4.87 \\
\hline \multicolumn{2}{|l|}{ Organization Structure } \\
\hline $\begin{array}{l}\text { I have no difficulties when I am required to contact colleagues who have } \\
\text { positions above or below me in the prevailing organizational structure. }\end{array}$ & 4.81 \\
\hline $\begin{array}{l}\text { I feel comfortable with the organizational structure that applied in my } \\
\text { work place. }\end{array}$ & 4.87 \\
\hline
\end{tabular}

Based on the data shown in Table 7, it shows that the high score given by the respondents indicating that they are strongly agree that the hotel already make them satisfied with their job based on the indicators as shown on the table. However, this thing needs to be maintained and improved by the superior and the management so the employee will still feel satisfy with their job. 
For the indicator of recognition, the score shows that the respondents strongly agree on the statements that the recognition at InterContinental Bali Resort such as giving compliment is a common thing that they do. The great communication between each employee shows from when they support each other in doing the work. Also, the management already provide good recognition such as rewarding for the employee who perform well in doing their job and promotion for the employee who can fulfill the requirement needed to gain promotion. This thing should be maintained of even improved if necessary.

Regarding the application of skills at InterContinental Bali Resort, the data shows that it is well done. The superior let the subordinates to express or apply the skills that they learned to get the job done as long as it can be done on time. The employee can select the equipment that they want to use, and decide how the procedure will be followed during their work. It makes the employee can freely do the job in their own way without ignoring the standard of the hotel. This thing will influence their working performance to be better and improve their job satisfaction.

As for the job involvement, the score shows that the respondents feel happy to be able working at InterContinental Bali Resort and agree that the work they do can reflect their identity. Based on the interview with the respondents, they said that they are happy and proud of their work. They feel happy and able to do their work well according to the job description and how the work organized by the management make them feel comfortable. It shows by the length of their stay loyal at InterContinental Bali Resort which is more than 15 years.

For the indicator of success, the data shows that the respondents find their selves capable to achieve and complete the work. Also taking every job that they do as important job so they really do it seriously with their competencies. The manager admitted that there are indeed some variety job that need to be done by the employee and they look capable in finishing their job. But still, the management think that some of the employee can do their job better if they have better skills, in order to achieve that some improvement need to be done.

Regarding to the work groups, the score shows that the employee can do the work in group quiet well. It's showed when the superior makes the employee have to do the work in group, the work can be done faster and the mistake that occur can be minimized. While in term of providing the assistance, some of the employee think that their colleague not really helping them when they facing difficulties. It's because they are currently busy with their own job or didn't see their co-worker having difficulties in doing their job. Some improvement can be done by the superior to enhance the work groups.

In term of supervision, from the score given by the respondents it shows that they are strongly agree that their superior already giving clear direction and assistance regarding the task that they need to do and how the quality of their performance in doing their job. It is because the supervision or leadership style used by their boss (superior) is quiet flexible depends on the condition that currently faced and suitable with the employee working ethic. This thing should be maintained or even improved so there will be better boundaries between the superior and subordinates.

As for the indicator of participation, the score on the data shows that the respondents strongly agree that the management give them the opportunity if they wanted to give advice for the management in term of improvement or during the discussion. The manager admitted that he like to do discussion with his subordinates regarding to some problem that they currently faced, and he also giving them the opportunity to give their advice. He also said that he will consider any advice given by them but it seems like there are some employee who still feeling shy to deliver their advice. So, improvement toward this indicator can be done to enhance the employee participation.

For the indicator of role conflict, the respondents also strongly agree that they are able to understand their role and the purpose of the job description well. It can be seen from how they able to do

8 | Barista: Jurnal Kajian Bahasa dan Pariwisata, Volume 7 Nomor 1, 2020: 1-11 
their roles and finish the job well based on their position also from the small number of mistake that they have done. This thing needs to be maintained in order to keep the good quality of work.

The last for the indicator of organizational structure, the data shows that the respondents strongly agree that they don't have any problem in communicating with their colleagues or employer and feel comfortable working at InterContinental Bali Resort. The respondents also don't have problem with the organization structure that prevails in the hotel. It is showed from the good team work and less miscommunication that occur during the works. Even though they have good communication, there's still the feeling of different in seniority and authority during the work. So, it will be better if this thing can be improved and maintained to enhance the job satisfaction.

To summarize the explanation above and the lowest score obtained for the indicator of Job Satisfaction. There are several action plans that are suggested to be done in order to analyse employee job satisfaction at Food \& Beverage Department in InterContinental Bali Resort. As for the proposed recommendations will be presented in Table 8 .

Table 8. Improvements Need per Indicator

\begin{tabular}{|c|c|c|c|}
\hline $\mathbf{N}$ & Indicator & Improvement Needed & Remarks \\
\hline 1 & Security. & $\begin{array}{l}\text { It is advised for the management to plan work in turns for } \\
\text { the employee and make a statement that can ensure and } \\
\text { relieves the employee anxiety about their job security. }\end{array}$ & \multirow{2}{*}{$\begin{array}{l}\text { This is urgent to be handled, } \\
\text { since it won't cost much and will } \\
\text { improve employee job } \\
\text { satisfaction in the hotel. }\end{array}$} \\
\hline 2 & Pay. & $\begin{array}{l}\text { It is recommended for the hotel to consider indirect } \\
\text { compensation (insurance, pension) going together with } \\
\text { direct compensation to gain employee satisfaction. }\end{array}$ & \\
\hline 3 & $\begin{array}{l}\text { Recognitio } \\
\text { n. }\end{array}$ & $\begin{array}{l}\text { It is suggested if the company can consider about the } \\
\text { recognition of employee without looking and considering } \\
\text { the seniority it might increase the level of satisfaction. }\end{array}$ & \multirow{7}{*}{$\begin{array}{l}\text { This aspect needs to be } \\
\text { maintained and improved if } \\
\text { possible. }\end{array}$} \\
\hline 4 & $\begin{array}{l}\text { Application } \\
\text { of Skills. }\end{array}$ & $\begin{array}{l}\text { It is advised to maintain the application of skills by giving } \\
\text { the subordinates an opportunity to complete the task in } \\
\text { their own way as long as it can be finished according to } \\
\text { InterContinental SOP. }\end{array}$ & \\
\hline 5 & $\begin{array}{l}\text { Job } \\
\text { Involvemen } \\
\text { t. }\end{array}$ & $\begin{array}{l}\text { It is suggested for the superior to conduct meeting } \\
\text { regarding the job involvement to know which part that } \\
\text { makes staff feel unhappy. Then, try to solve it so that the } \\
\text { level of job satisfaction can be increasing. }\end{array}$ & \\
\hline 6 & Success. & $\begin{array}{l}\text { To maintain the employee performance, it is advised that } \\
\text { the management might conduct soft skill development } \\
\text { training like problem solving and time management. }\end{array}$ & \\
\hline 7 & $\begin{array}{l}\text { Work } \\
\text { Group. }\end{array}$ & $\begin{array}{l}\text { It is suggested if the superior can help the subordinates to } \\
\text { be more sensible in helping their co-worker while they are } \\
\text { able to do it. }\end{array}$ & \\
\hline 8 & Supervision & $\begin{array}{l}\text { It is recommended for the superior to observe their } \\
\text { subordinates when applying specific leadership style } \\
\text { because different people might work well in different } \\
\text { leadership style. That thing will help them work better and } \\
\text { feel satisfied with their job. }\end{array}$ & \\
\hline 9 & $\begin{array}{l}\text { Participatio } \\
\text { n. }\end{array}$ & $\begin{array}{l}\text { To make the employee be more active, it is suggested for } \\
\text { the superior to encourage the subordinates more in } \\
\text { participating to give their input. }\end{array}$ & \\
\hline 10 & $\begin{array}{l}\text { Role } \\
\text { Conflict. }\end{array}$ & $\begin{array}{l}\text { In order to keep up or increase the good work of the } \\
\text { employee, it is recommended for the superior to remind } \\
\text { the job description of each positions when they do } \\
\text { morning briefing every day. }\end{array}$ & \multirow{2}{*}{$\begin{array}{l}\text { This aspect needs to be } \\
\text { maintained and improved if } \\
\text { possible. }\end{array}$} \\
\hline 11 & $\begin{array}{l}\text { Organizatio } \\
\text { n Structure. }\end{array}$ & $\begin{array}{l}\text { It is suggested for the superior to be more open and try to } \\
\text { embrace the subordinates so they will have better } \\
\text { communication which will impacting to the employee job } \\
\text { satisfaction. }\end{array}$ & \\
\hline
\end{tabular}




\section{CONCLUSION}

Based on the discussion above, it can be concluded that employee job satisfaction at InterContinental Bali Resort which represent the theory of Gruneberg about job satisfaction. The result from discussion of the lowest indicator score shows that there is some employee who feel that their wages not match with their performance and some of the employee also not sure whether their current wages can fulfill their daily need. As for term of job security, many old (senior employee) feel worried about losing their job in this pandemic situation. Also, some of the employee feel not sure whether their current wages can be used for future needs because of unpredictable current situation.

To ensure these problems are handled appropriately, various improvement is needed to overcome this problem to enhance or maintain employee job satisfaction even during this COVID-19 situation. Taking some corrective action plan and reconsidering their wages is suggested to make the employee feel more secure about their job. In order to improve the employee job satisfaction at Food \& Beverage Department in InterContinental Bali Resort, the suggestion of corrective action planning can be seen in detail on Table 8 with remarks for every indicator.

During the implementation of this research, the researcher faced some things such as; advantage and disadvantage also the challenge and opportunity of this research that currently conducted. The advantage is this research able to know how the employee job satisfaction at InterContinental Bali Resort especially on F\&B service department. Then the research object also emphasizes the employee job satisfaction in F\&B service department which is the one who have to meet and handle the guest every day and act as the front part that will create guest provision. So, doing analysis on employee job satisfaction is necessary to improve their quality of services. As for the disadvantage of this research is the result of the data gained from the respondent's perspective is affected with the current condition or external factor which is COVID-19. It makes the result is less accurate compared if the research conducted in normal condition.

The challenge that faced when conducting the research is due to COVID-19 the employee where divided into several shift so it requires more time to collect the data from questionnaire. When doing interview the employee tend to answer it shortly which is only the point because they don't have much time since there is a lot of online training given by the hotel so several interview needed to confirm the data. Also, due to this pandemic situation I can't gain accurate date when doing observation because they employee didn't work much due to a few numbers of the guest. As for the triangulation data for senior hospitality practitioner is done through online webinar platform. This thing is done to ensure that the research conducted can be done ontime based on the timeline that have been set.

As the researcher of this research, I would like to suggest for this research to be used as references or example for other researcher who want to conduct the similar research especially for the research that will be conducted in Bali. For the future, this study also can be used as learning material to enhance the knowledge about employee job satisfaction using the theory of Gruneberg, (1979).

\section{DAFTAR PUSTAKA}

Anju K. J. (2015). A study on Job satisfaction of Employees in BPCL - Kochi Refinery Limited, Ambalamugal.

Aprameya, A. (2016). Cross Tabulation: How It Works and Why You Should Use It. Retrieved from https://humansofdata.atlan.com/2016/01/cross-tabulation-how-why/

Bernstein, A. (2011). A Herzbergian look at academic librarians and job satisfaction. Georgia Library Quarterly, 48(3), 1-15.

Brace, I. (2008). Questionnaire Design: How to Plan, Structure and Write.

Gruneberg, M. M., 1979. Understanding Job Satisfaction. 1st ed. London: The Macmillan Press LTD.

10 | Barista: Jurnal Kajian Bahasa dan Pariwisata, Volume 7 Nomor 1, 2020: 1-11 
McLeod, S. (2018). Questionnaire: Definition, Examples, Design and Types. Retrieved from https://www.simplypsychology.org/questionnaires.html

Middleton, F. (2019). Reliability vs validity: what's the difference? Retrieved from https://www.scribbr.com/methodology/reliability-vs-validity/

Mollah, M. S. (2015). A Critical Analysis of Employee Job Satisfaction: A Case Study of . European Journal of Business and Management, 7.

Singarimbun \& Efendi, 1995. Metode Penelitian Survey. Jakarta: PT Pustaka LP3ES.

Stone, R. J., 2011. Human Resources Management. 7th ed. Milton Qld : John Wiley \& Sons

Australia Ltd.

Sugiyono, 2010. Cara Muda Menyusun Skripsi, Tesis, dan Disertasi (STD). Bandung:

Alfabeta.

Sujarweni, V. W., 2014. Metode Penelitian: Lengkap, Praktis dan Mudah Dipahami.

Yogyakarta: Pustaka Baru Press.

Surbhi. (2017). Difference Between Qualitative and Quantitative Data. Retrieved from https://keydifferences.com/difference-between-qualitative-and-quantitative-data.html

Sykes, L. (2016). The meaning of the MEAN, and other statistical terms commonly used in medical research. Retrieved from http://www.scielo.org.za/scielo.php?script=sci_arttext\&pid=S001185162016000600009 